\title{
Hearing loss and hypertension: exploring the linkage
}

John Adekunle Babarinde ${ }^{1}$, Adebolajo A. Adeyemo ${ }^{1,2^{*}}$ (iD and Abiodun Moshood Adeoye $e^{3,4}$

\begin{abstract}
Background: The inner ear vascular system may be disrupted by systemic hypertension causing inner ear hemorrhage and resulting in progressive or sudden hearing loss. Constriction of the labyrinthine artery secondary to atherosclerosis seen in high BMl and waist/hip circumference-risk factors of hypertension-could also occur with resultant hearing loss. Thus, hypertension could predispose to increased risk of hearing loss. This crosssectional study assessed the hearing thresholds of hypertensive patients and sought to determine the association between hypertension and hearing loss among patients attending cardiology clinic in tertiary hospital in Nigeria.

Results: The study population was 500 individuals equally divided into subject and control arms. The mean age of the subjects and controls was $47.2 \pm 7.4$ years and $46.9 \pm 7.5$ years respectively. Hearing loss-mainly mild sensorineural hearing loss - was seen in 30\% of the subjects and $0.4 \%$ of the controls. The hearing loss was bilateral in all subjects and slightly worse in the right ears. The hearing loss worsened with increased age, severity, and duration of hypertension; however, there was no association between the hearing loss and body mass index.

Conclusion: There is an association between hypertension and hearing loss, though most of the hypertensive subjects had mild sensorineural hearing loss. The prevalence and severity of the hearing loss worsens with the degree of hypertension. Incorporating regular audiological assessment for hypertensive patients could improve the quality of care for hypertension and quality of life for hypertensive patients.
\end{abstract}

Keywords: Blood pressure, Hearing loss, Hearing threshold, Hypertension, Body mass index

\section{Background}

Hypertension is a chronic medical condition characterized by elevated arterial blood pressure [1]. According to WHO/International Society of Hypertension guidelines, hypertension is defined as systolic blood pressure $\geq 140$ $\mathrm{mmHg}$ and diastolic blood pressure $\geq 90 \mathrm{mmHg}$, and/or self-reported treatment of hypertension with antihypertensive medications taken in preceding 2 weeks. The classification of adult blood pressure is divided into the normal group of systolic blood pressure (SBP) $<120$ $\mathrm{mmHg}$ and diastolic blood pressure (DBP) $<80 \mathrm{mmHg}$, prehypertension SBP: $120-139 \mathrm{mmHg}$ and DBP: $80-90$

\footnotetext{
* Correspondence: adebolajo@gmail.com

'Department of Otorhinolaryngology, University College Hospital, Ibadan, Nigeria

${ }^{2}$ Institute of Child Health, College of Medicine, University of Ibadan, PMB 5017, Ibadan, Nigeria

Full list of author information is available at the end of the article
}

$\mathrm{mmHg}$, first-degree hypertension SBP: $140-159 \mathrm{mmHg}$ and DBP: 90-99 $\mathrm{mmHg}$, second-degree hypertension SBP $>160 \mathrm{mmHg}$ and DBP > $100 \mathrm{mmHg}$ [2].

Hypertension cuts across all socioeconomic strata and it is a global public health challenge [3, 4]; the burden of hypertension (and other non-communicable diseases) is rapidly increasing, especially on the African continent which may be the most affected region in the world [57]. Hypertension affects about 1 billion people globally and it is the main risk factor for many other cardiovascular diseases [8-10]. The overall crude prevalence of hypertension in Nigeria ranges from 6.2 to $48 \%$ and 10 to $47.3 \%$ in males and females respectively [11], this may form a large proportion of the total burden of hypertension in Africa because Nigeria is the most populous black nation with an estimated population of over 170 million [8]. This burden of hypertension may continue 
to increase due to the increasing adult population and lifestyle changes of Nigerians $[12,13]$.

Hypertension is an independent risk factor for hearing loss due to the possible impact on the microcirculation of the inner ear; the subsequent degeneration of the inner ear will lead to hearing loss. The effect of hypertension on the inner ear can be manifested by thrombus formation secondary to damage to arterial inner lining from the increased pressure [14]. Occlusion of blood flow can lead to cell death in distal structures. Atherosclerosis can also occur in the cochlear arteries following long standing hypertension with fat collection in the damaged arteries. High body mass index (BMI) and large waist circumference, which are risk factors of hypertension, are associated independently with an increased risk of hearing loss [15]. Obesity-related atherosclerosis may lead to stiffening and constriction of the internal auditory artery and reduction in cochlear blood flow. This can lead to capillary constriction within the stria vascularis, cell death, and hearing loss [16].

Long-standing hypertension has been reported as a possible cause of hearing impairment in some adult population. Studies have shown a link between hypertension and hearing loss. Some of these studies have also shown relationship between the duration and severity of hypertension and the prevalence and degree of hearing loss [17-20].

Hearing impairment is a neglected public health problem in developing countries [21], even though about half of all cases of hearing impairment are avoidable through prevention, early diagnosis, and management $[22,23]$. The large burden of hypertension in Africa may contribute to the huge burden of hearing impairment in the region. Therefore, there is a need for further studies to validate the association between hearing loss and hypertension. This will serve as a basis for a greater integration between cardiologists, ENT surgeons, audiologist, speech therapists, and other healthcare professionals to improve the quality of care and rehabilitation of individuals with hearing loss. This study therefore sought to determine the prevalence, patterns, and types of hearing loss among individuals with arterial hypertension, and the association between hearing loss, the degree of hypertension, and the body mass index.

\section{Methods}

This was a hospital-based cross-sectional study conducted among hypertensive patients and an equal number of age-matched and sex-matched non-hypertensive subjects. Consenting adults aged 18-59 years who met the eligibility criteria were randomly recruited from the Cardiology Medical Outpatients' clinic between February and June 2019. The inclusion criterion was a diagnosis of systemic arterial hypertension while exclusion criteria were positive family history of hearing impairment, history of prolonged exposure to noise, ongoing ear disease or history of ear infection, ototoxic drugs (including diuretics), and co-morbidities such as diabetes mellitus, hyperlipidemia, stroke, and chronic kidney disease. The control group included healthy adult patients' relatives and hospital staff without hypertension or any of the exclusion criteria. A sample size of 250 participants in each arm was determined based on a similar study that gave a prevalence of $16.4 \%$ [17] as hearing loss in hypertensive patients. General physical examination and otoscopy were done for all participants, those with wax impaction were offered ear syringing before continuing with other aspects of the study. The blood pressure was determined with a mercury sphygmomanometer (Accoson Dekamet, England) from the mean of two readings taken at least 15 min apart after the participants had rested for at least 10 min. Hypertension was defined and classified according to WHO/International Society of Hypertension guidelines [2]. Weight was determined with a weighing scale RGZ-160 (Lincoln Mark Medical England) and height assessed with a stadiometer RGZ-160 (Lincoln Mark Medical, England). The values obtained were recorded in kilograms and meters respectively and rounded up to two decimal points. The body mass index (BMI) was calculated and categorized according to WHO standard: $\mathrm{BMI}<18.5 \mathrm{~kg} / \mathrm{m}^{2}$ as underweight, $18.5-24.9 \mathrm{~kg} / \mathrm{m}^{2}$ as normal weight, $25.0-29.9 \mathrm{~kg} / \mathrm{m}^{2}$ as overweight, $30-34.9 \mathrm{~kg} / \mathrm{m}^{2}$ as class I obesity, $35.0-39.0$ $\mathrm{kg} / \mathrm{m}^{2}$ as class II obesity and BMI $>40.0 \mathrm{~kg} / \mathrm{m}^{2}$ is classified as class III obesity [24]. Waist and hip circumferences were measured with a tape rule and the values were recorded in centimeters. Waist to hip ratio was classified according to WHO standard: high risk $>1.0$ (men), > 0.85 (women), moderate risk 0.9-1.0 (men), 0.80-0.85 (women), and low risk $<0.90$ (men) and < 0.80 (women) [25]. Tympanometry and pure tone audiometry were done in a sound - proof audiology booth with a duly calibrated tympanometer (AT 235 Interacoustics) and diagnostic audiometer (AD 629 Interacoustics) respectively. The tympanograms were classified to type $A, B, C, A_{S}$, or $A_{D}$ [26]. Hearing threshold was classified according to WHO: normal

Table 1 Age distribution of the participants, mean blood pressure values among participants

\begin{tabular}{lll}
\hline $\begin{array}{l}\text { Age category } \\
\text { (years) }\end{array}$ & $\begin{array}{l}\text { Subjects } \\
\boldsymbol{N}(\%)\end{array}$ & $\begin{array}{l}\text { Controls } \\
\boldsymbol{N}(\%)\end{array}$ \\
& $\boldsymbol{N}=\mathbf{2 5 0}$ & $\boldsymbol{N}=\mathbf{2 5 0}$ \\
\hline $20-29$ & $4(1.6)$ & $6(2.4)$ \\
$30-39$ & $36(14.4)$ & $39(15.6)$ \\
$40-49$ & $101(40.4)$ & $97(38.8)$ \\
$50-59$ & $109(43.6)$ & $108(43.2)$ \\
\hline
\end{tabular}


Table 2 Degree of hypertension and distribution of hearing status among the participants

\begin{tabular}{|c|c|c|c|c|}
\hline \multirow{2}{*}{$\begin{array}{l}\text { Hypertension } \\
\text { severity }\end{array}$} & \multicolumn{3}{|l|}{ Hearing status } & \multirow[t]{2}{*}{$p$ value } \\
\hline & $\begin{array}{l}\text { Normal hearing } \\
N(\%)\end{array}$ & $\begin{array}{l}\text { Hearing loss } \\
N(\%)\end{array}$ & Total & \\
\hline $\begin{array}{l}\text { First degree } \\
\text { hypertension }\end{array}$ & $153(76.2)$ & $48(23.8)$ & 201 & 0.01 \\
\hline $\begin{array}{l}\text { Second degree } \\
\text { hypertension }\end{array}$ & $22(44.9)$ & $27(55.1)$ & 49 & \\
\hline
\end{tabular}

hearing threshold $(<25 \mathrm{~dB})$, mild hearing loss $(26-40$ $\mathrm{dB})$, moderate hearing loss (41-55 dB), moderately severe hearing loss (56-70 dB), severe hearing loss (70-90 $\mathrm{dB})$, and profound hearing loss (>90 dB) [27]. The hearing thresholds in the better ear were used for further analysis. Chi-square test was used to determine the relationship between categorical variables, and Students $t$ test was used to determine the relationship between quantitative variables. Linear regression was done to test for association between variables. The level of significance was set at a $p$ value of less than 0.05 .

\section{Results}

A total number of 500 participants participated in the study. The mean age of the subjects was $47.2 \pm 7.4$ years while that of the control group was $46.9 \pm 7.5$ years (Table 1). Male to female ratio of the subjects was 1:1.7 while that of the control was 1:1.9. All the hypertensive patients were right-handed.
First degree hypertension was seen in 201 subjects while the remainder had second degree hypertension (Table 2). Majority (96.8\%) of the hypertensive participants studied had normal tympanogram in both ears while the remaining $3.2 \%$ had either type $A_{s}, B$, or $C$ tympanogram. Hearing loss was present in 75 subjects $(30.0 \%)$ while only $1(0.4 \%)$ of the controls had hearing loss $(P=0.0001)$, among the subjects with stage 1 hypertension, $23.8 \%$ had hearing loss (see Table 2 and Fig. 1). Mean pure tone average was slightly worse in the right ear than in the left in both groups. The pure tone audiograms of the subjects with hearing loss were sloping pattern in majority (95\%) while the rest (5\%) had a flat pattern; $96 \%$ of the hearing loss cases were sensorineural hearing loss, while the remainder was mixed hearing loss.

Out of the 75 subjects with hearing loss, 60 subjects had diagnosis of hypertension of greater than 3 years' duration. Age was associated with increased prevalence of hearing loss, the older age group had higher prevalence of hearing loss compared to the younger age group, and no relationship was seen between hearing loss and gender among the hypertensive subjects. Thus, age, severity, and duration of hypertension were found to have statistically significant association with increased prevalence of hearing loss (Table 3).

Majority of the hypertensive subjects were overweight, but the low-risk category of waist-hip ratio was predominant among the subjects. Increase in the BMI and the waist-hip ratio was not associated with increased prevalence of hearing loss (Table 4).

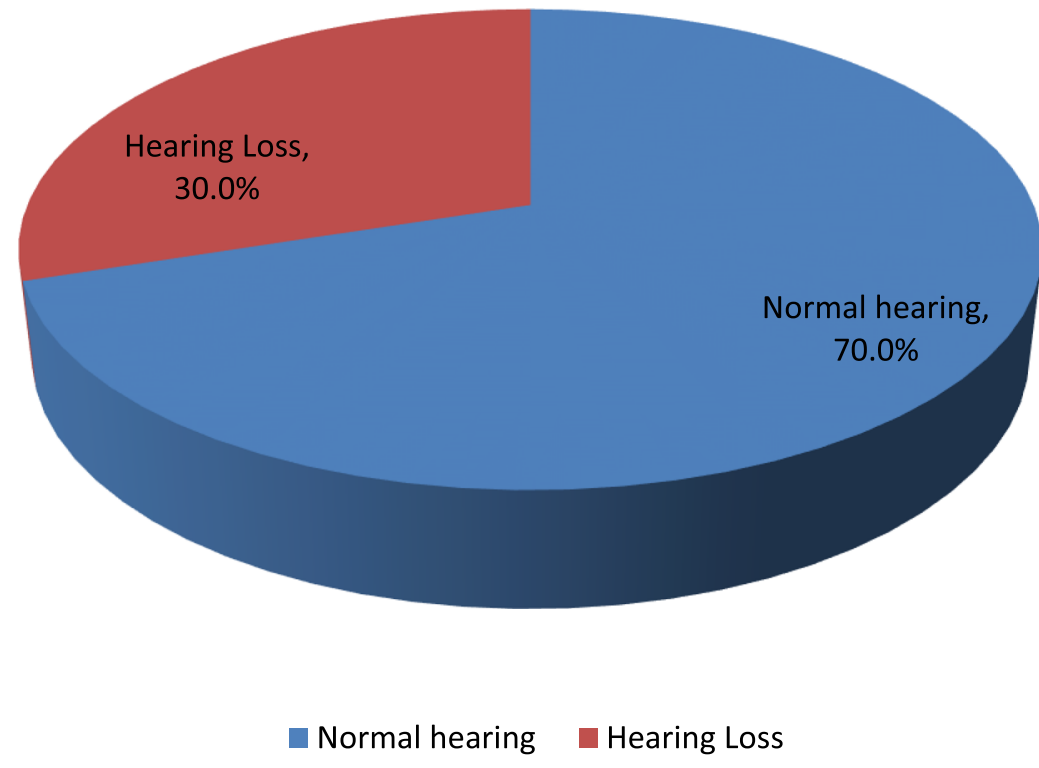

Distribution of hearing status among the hypertensive participants

Fig. 1 Distribution of hearing status among the hypertensive participants 
Table 3 Association between age, gender, severity, and duration of hypertension with hearing status among subjects

\begin{tabular}{|c|c|c|c|c|}
\hline \multirow[t]{2}{*}{ Variables } & \multicolumn{3}{|c|}{ Hearing status $N(\%)$} & \multirow[t]{2}{*}{$p$ value } \\
\hline & Normal hearing & Hearing loss & Total & \\
\hline Severity & & & & 0.010 \\
\hline First degree & $153(76.2)$ & $48(23.8)$ & 201 & \\
\hline Second degree & $22(44.9)$ & $27(55.1)$ & 49 & \\
\hline Duration of hypertension & & & & 0.0001 \\
\hline Less than 1 year & $16(72.7)$ & $6(27.3)$ & 22 & \\
\hline $1-3$ years & 79 (89.8) & $9(10.2)$ & 88 & \\
\hline$>3$ years & $80(57.1)$ & $60(42.9)$ & 140 & \\
\hline Age group & & & & 0.0001 \\
\hline $20-29$ & $3(75.0)$ & $1(25.0)$ & 4 & \\
\hline $30-39$ & $35(97.2)$ & $1(2.8)$ & 36 & \\
\hline $40-49$ & $72(71.3)$ & $29(28.7)$ & 101 & \\
\hline $50-59$ & $65(59.6)$ & $44(40.4)$ & 109 & \\
\hline Sex & & & & 0.555 \\
\hline Male & $63(70.0)$ & $27(30.0)$ & 90 & \\
\hline Female & $112(70.0)$ & $48(30.0)$ & 160 & \\
\hline
\end{tabular}

Majority of the subjects $(79.2 \%)$ use calcium channel blockers either as a single drug or in combination with other class of antihypertensives, 34.4\% use angiotensin II receptor blockers, $23.2 \%$ use angiotensin converting enzyme inhibitors, while $11.2 \%$ use $\alpha$ Metildopa as either single drug or in combination with other antihypertensive and $24.4 \%$ use antiplatelets in combination with antihypertensive medications. There was no significant association between class of antihypertensives used and hearing loss.

After multivariate analysis, severity of hypertension, older age, duration of usage of anti-hypertensive medications, and post-diagnosis duration of hypertension were observed to be predictors of hearing loss among the subjects (Table 5).

\section{Discussion}

The proportion of hypertensive patients in the study who had hearing loss was $30 \%$; this is like a trend that has been observed in other studies [28, 29]. However, this study showed that the association between hypertension and hearing loss was statistically significant. The huge burden of hypertension in Africa could therefore be a significant contributor to the silent and often overlooked burden of hearing loss on the African continent. Although all subjects with hearing loss had bilateral

Table 4 Relationship between body mass index and wait/hip ratio with hearing status

\begin{tabular}{|c|c|c|c|c|}
\hline \multirow[t]{2}{*}{ Variables } & \multicolumn{3}{|c|}{ Hearing status $N(\%)$} & \multirow[t]{2}{*}{$p$ value } \\
\hline & Normal hearing & Hearing loss & Total & \\
\hline BMI grading & & & & 0.776 \\
\hline Underweight & $1(100.0)$ & 0 & 1 & \\
\hline Normal & $59(73.8)$ & $21(26.2)$ & 80 & \\
\hline Overweight & $62(67.4)$ & $30(32.6)$ & 92 & \\
\hline Obese & $52(68.4)$ & $24(31.6)$ & 76 & \\
\hline Others-morbidly obese & $1(100.0)$ & 0 & 1 & \\
\hline Waist/hip ratio category & & & & 0.716 \\
\hline High risk & $48(70.6)$ & $20(29.4)$ & 68 & \\
\hline Moderate risk & $66(72.5)$ & $25(27.5)$ & 91 & \\
\hline Low risk & $61(67.0)$ & $30(33.0)$ & 91 & \\
\hline
\end{tabular}


Table 5 Multivariate analysis of risk factors of hearing loss

\begin{tabular}{llll}
\hline Variables & Odds ratio & 95\% confidence interval & p value \\
\hline Severity of hypertension & 2.275 & $1.194-4.334$ & 0.012 \\
Age (years) & 2.277 & $1.489-3.483$ & 0.0001 \\
Duration of usage of anti-hypertensive drugs & 1.372 & $1.019-1.846$ & 0.037 \\
Post-diagnosis duration of hypertension & 2.703 & $1.617-4.518$ & 0.0001 \\
\hline
\end{tabular}

hearing loss, yet, the hearing threshold was slightly worse in the right ear compared to the left ear. This may be related to the handedness of the hypertensive subjects, who were all right-handed. The handedness has been suggested as likely cause of prolonged noise exposure in the corresponding ear [30,31].

The predominance of SNHL in the hypertensive subjects $[31,32]$ could be secondary to microcirculatory insufficiency in the inner ears due to the microangiopathy caused by hypertension [33, 34].The observed SNHL was mainly of the mild classification, though mild and moderate SNHL have been reported by some other studies of hearing loss in hypertensive patients. The differences in the observations reported may be due to difference in ages of the study participants-studies with older participants tend to report worse category of hearing loss [20, 28, 32]. It was observed that while about a quarter of participants with stage 1 hypertension had hearing loss, at least half of the participants with stage 2 hypertension developed hearing loss demonstrating a progressively increasing prevalence of hearing loss with worsening severity of the hypertension [20,28]. A similar observation of increase in prevalence of hearing loss with increased duration of the hypertension was also observed [31]. However, the class of antihypertensive drug used was not significantly associated with hearing loss. These observations demonstrated the negative impact of hypertension on the inner ear with corresponding worsening of the hearing acuity. While some authors had identified association of BMI with the increased risk of hearing loss [17], this observation was not confirmed in the index study. We attribute our observation to the study participants being mainly in normal or overweight BMI category and in the low-risk group of waist-hip ratio [35].

\section{Conclusions}

There is a demonstrable association between systemic arterial hypertension and hearing loss. The observed hearing loss is mainly sensori-neural, and it worsens with both the severity and duration of hypertension. Incorporating regular audiological assessment for hypertensive patients could improve the quality of care for hypertension and quality of life for hypertensive patients.

\section{Abbreviations}

BMI: Body mass index; DBP: Diastolic blood pressure; ENT: Ear, nose, and throat; JNC 7: Seventh Joint National Committee; PTA: Pure tone audiometry;
SNHL: Sensorineural hearing loss; SBP: Systolic blood pressure; WHO: World Health Organization

\section{Acknowledgements \\ None declared}

\section{Authors' contributions}

$J A B$ and $A A A$ had a role in the conception, planning, data acquisition and analysis and writing up of the work, and manuscript development. AMA contributed to planning of the study and data acquisition, editing, and revision of the final manuscript. All authors have read and approved the final manuscript.

Funding

This article received no external funding

\section{Availability of data and materials}

The datasets used and/or analyzed during the current study are available from the corresponding author on reasonable request.

\section{Declarations}

Ethics approval and consent to participate

Ethical clearance was obtained from the University of Ibadan and University College Hospital, Ibadan Ethical Review Board (UI/EC/18//0180). Written informed consent was obtained from all the study participants.

Consent for publication

Not applicable

\section{Competing interests}

The authors declare that they have no competing interests.

\section{Author details}

${ }^{1}$ Department of Otorhinolaryngology, University College Hospital, Ibadan, Nigeria. ${ }^{2}$ Institute of Child Health, College of Medicine, University of Ibadan, PMB 5017, Ibadan, Nigeria. ${ }^{3}$ Department of Medicine, College of Medicine, University of Ibadan, Ibadan, Nigeria. ${ }^{4}$ Department of Medicine, University College Hospital, Ibadan, Nigeria.

Received: 17 June 2021 Accepted: 3 September 2021

Published online: 23 September 2021

\section{References}

1. World Health Organization (2013) A global brief on hypertension : silent killer, global public health crisis: World Health Day 2013. World Health Organization. https://apps.who.int/iris/handle/10665/79059

2. National high Blood Pressure Education Program (2004) The seventh report of the joint national committee of prevention, detection, evaluation and treatment of high blood pressure. National Heart, Lung and Blood Institute, $\mathrm{NIH}$, Bethesda

3. Kearney PM, Whelton M, Reynolds K, Muntner P, Whelton PK, He J (2005) Global burden of hypertension; analysis of worldwide data. Lancet 365(9455):217-223. https://doi.org/10.1016/S0140-6736(05)17741-1

4. Lim SS, Vos T, Flaxman AD, Danaei G, Shibuya K, Alair-Rohani H et al (2012) A comparative risk assessment of burden of disease and injury attributable to 67 risk factors and risk factor clusters in 21 regions, 1990-2010: a systematic analysis for the Global Burden of Disease Study 2010. Lancet 380(9859):2224-2260. https://doi.org/10.1016/S0140-6736(12)61766-8 
5. World Health Organization (2013) A global brief on hypertension: silent killer, global public health crises. https://apps.who.int/iris/handle/10665/ 79059. Accessed 15 Jun 2021.

6. Ibrahim MM, Damasceno A (2012) Hypertension in developing countries. Lancet 380(9841):611-619

7. Seedat YK (2000) Hypertension in developing sub-Saharan Africa. J Hum Hypertens 14(10-11):739-747. https://doi.org/10.1038/sj.jhh.1001059

8. Adeloye D, Basquill C, Aderemi AV, Thompson JY, Obi FA (2015) An estimate of the prevalence of hypertension in Nigeria. J Hypertens 33(2): 230-242. https://doi.org/10.1097/HJH.0000000000000413

9. Sola AO, Chinyere OI, Stephen AO, Kayode JA (2013) Hypertension prevalence in an urban and rural area of Nigeria. J Med Sci 4(4):149-154

10. Mbanya JC, Minkoulou EM, Salah JN, Balkau B (1998) The prevalence of hypertension in rural and urban Cameroon. Int J Epidemiol 27(2):181-185

11. Akinlua JT, Meakin R, Umar AM, Freemantle M (2015) Current prevalence pattern of hypertension in Nigeria: a systemic review. PLoS One 10(10): 01400. https://doi.org/10.1371/journal.pone.0140021

12. Kayime J, Wanyenze RK, Katamba A, Leontsini E, Nuwaha F (2013) Hypertension awareness, treatment, and control in Africa: a systematic review. BMC Cardiovasc Disord 13:54. https://doi.org/10.1186/1471-2261-13-54

13. Perkovic V, Huxley R, Wu Y, Prabhakaran D, MacMahon S (2007) The burden of blood pressure related disease: a neglected priority for global health. Hypertension 50(6):991-997. https://doi.org/10.1161/HYPERTENSIONAHA.107. 095497

14. Hinojosa R, Kohut RI (1990) Clinical diagnosis of anterior inferior cerebellar artery thrombosis. Autopsy and Temporal bone histopathologic study. Ann Otol Rhinol Laryngol 99(4pt1):261-272

15. Curhan SG, Eavey R, Wang M, Stamfer MJ, Curhan GC (2013) Body mass index, waist circumference, physical activity, and risk of hearing loss in women. Am J Med 126(12):1142-1142.e8. https://doi.org/10.1016/j.a mjmed.2013.04.026

16. Shashikala KT, Srinivas K (2015) Sensorineural hearing loss in young adults with BMl of 25 or more. J Evol Med Dent Sci 4(29):4997-5002 https://link.ga le.com/apps/doc/A471274897/AONE?u=anon c066085d\&sid=googleSchola r\&xid=4a3bf3de. Accessed 24 Jul 2021

17. Yikawe SS, Iseh KR, Sabir AA, Inoh MI, Solomon JH, Aliyu N (2017) Aug 18, Cardiovascular risk factors and hearing loss among adults in a tertiary center of Northwestern Nigeria. World J Otorhinolaryngol Head Neck Surg 4(4): 253-257. https://doi.org/10.1016/j.wjorl.2017.05.015

18. Sogebi OA (2013) Assessment of the risk factors for hearing loss in adult Nigerian population. Niger Med J 54(4):244-224. https://doi.org/10.4103/03 00-1652.119648

19. Kuang D, Yu YY, Tu C (2019) Bilateral high-frequency hearing loss is associated with elevated blood pressure and increased hypertension risk in occupational noise exposed workers. PLoS One 14(9):e0222135. https://doi. org/10.1371/journal.pone.0222135

20. Yikawe SS, Uguru SU, Solomon JH, Adamu AM, Damtong F, Osisi K, Adeyeye FM (2019) Hearing loss among hypertension patients. Egypt J Otolaryngol 35(3):307-312. https://doi.org/10.4103/ejo.ejo_16_19

21. Stevens $G$, Flaxman S, Brunskill E, Mascarenhas M, Mathers CD, Finucane M (2013) Global and regional hearing impairment prevalence: an analysis of 42 studies in 29 countries. Eur J Pub Health 23(1):146-152. https://doi.org/10.1 093/eurpub/ckr176

22. Ullauri A, Smith A, Espinel M, Jimenez C, Salazar C, Castrillon R (2014) WHO ear and hearing disorders survey: Ecuador national study 2008-2009. Conference Papers in Science. https://doi.org/10.1155/2014/847526

23. Pascolini D, Smith A (2009) Hearing impairment in 2008: a compilation of available epidemiological studies. Int J Audiol 48(7):473-485. https://doi. org/10.1080/14992020902803120

24. World Health Organization (2021) Body mass index. https://www.euro.who. int/en/health-topics/disease-prevention/nutrition/a-healthy-lifestyle/bodymass-index-bmi. Accessed 15 Jun 2021.

25. World Health Organization (2008) Waist circumference and waist-hip ratio: report of a WHO expert consultation. https://www.who.int/publications/i/ item/9789241501491. Accessed 15 Jun 2021

26. Onusko E (2004) Tympanometry. Am Fam Physician 70(9):1713-1720

27. Harrell RW (2002) Pure tone evaluation. In: Katz J (ed) Handbook of Clinical Audiology, 5th edn. Lippincott Williams \& Wilkins, Philadelphia, pp 71-87

28. Agarwal S, Mishra A, Jagade M, Kasbekar V, Nagle SK (2013) Effects of hypertension on hearing. Indian J Otolaryngol Head Neck Surg 65(S3):614618. https://doi.org/10.1007/s12070-013-0630-1
29. Petit L, Simon G, Johot M, Anderson F, Berton T, Zago L et al (2007) Right hemispheric dominance for auditory attention and its modulation by eye position: an event released fMRI study. Restor NeurolNeurosci 25(3-4):211-225

30. Seidman MD, Siegel B, Shah P, Bowyer SM (2013) Hemispheric dominance and cell phone use. JAMA Otolaryngol Head Neck Surg 139:466-470

31. Mondelli MFCG, Lopes AC (2009) Relation between arterial hypertension and hearing loss. Int Arch Otorhinolaryngol 13(1):63-68

32. Vemanna P, Patil Kl, Prabhu RM, Rao BPN, Viswanatha B (2019) Hearing impairment in essential hypertensive patients: a prospective study at a tertiary care center. Res Otolaryngol 8(2):20-24. https://doi.org/10.5923/j. otolaryn.20190802.02

33. Carrasco VN, Prazima J, Faber JE (1990) Cochlear microcirculation effects of adrenergic agonists on arteriole diameter. Arch Otolaryngol Head Neck Surg 116(4):411-417. https://doi.org/10.1001/archotol.1990.01870040033009

34. Gates GA, Cobb JL, D'Agostino RB, Wolf PA (1993) The relation of hearing in the elderly to the presence of cardiovascular disease and cardiovascular risk factors. Arch Otolaryngol Head Neck Surg 119(2):156-161. https://doi.org/1 0.1001/archotol.1993.01880140038006

35. Shargorodsky J, Curhan SG, Eavey R, Curhan GC (2010) A prospective study of cardiovascular risk factors and incident hearing loss in men. Laryngoscope 120(9):1887-1891. https://doi.org/10.1002/lary.21039

\section{Publisher's Note}

Springer Nature remains neutral with regard to jurisdictional claims in published maps and institutional affiliations.

\section{Submit your manuscript to a SpringerOpen ${ }^{\circ}$ journal and benefit from:}

- Convenient online submission

Rigorous peer review

- Open access: articles freely available online

High visibility within the field

- Retaining the copyright to your article

Submit your next manuscript at $>$ springeropen.com 